\title{
Lung hernia following minithoracotomy for epicardial lead placement
}

\author{
Jessamy Diana Bagenal, ${ }^{1}$ Radek Capoun, ${ }^{2}$ Gianluca Casali ${ }^{3}$
}

${ }^{1}$ Department of General Surgery, Bristol Royal Infirmary, Bristol, UK ${ }^{2}$ Department of Cardiothoracic, Bristol Royal Infirmary, Bristol, UK

${ }^{3}$ Department of Thoracics, Bristol Royal Infirmary, Bristol, UK

\section{Correspondence to} Jessamy Diana Bagenal, jessamy.bagenal@gmail.com

\section{DESCRIPTION}

A 68-year-old gentleman was referred to the thoracic outpatient clinic 6 months after minithoracotomy and repositioning of an epicardial lead for his cardiac resynchronisation therapy-pacemaker to improve synchrony in dilated cardiomyopathy. His significant medical history also included chronic obstructive pulmonary disease, hypertension, chronic kidney disease stage 3 and depression. His original procedure was uncomplicated, but within 1 month he noticed a large $(15 \times 15 \mathrm{~cm})$ lump that extended from his axilla down to his left chest wall. It was uncomfortable and had to be manually reduced. He suffered from increased shortness of breath and it compromised his ability to cough. A CT chest scan was performed and revealed an obvious lung hernia (figure 1). His symptoms

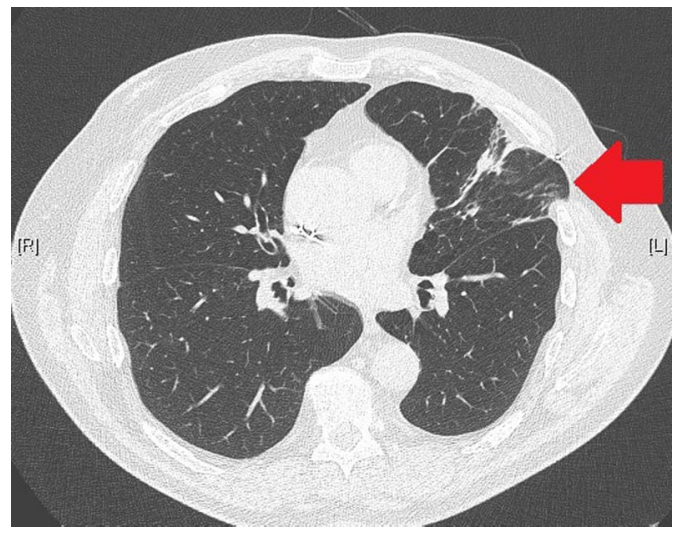

Figure 1 CT chest: evidence of lung hernia.

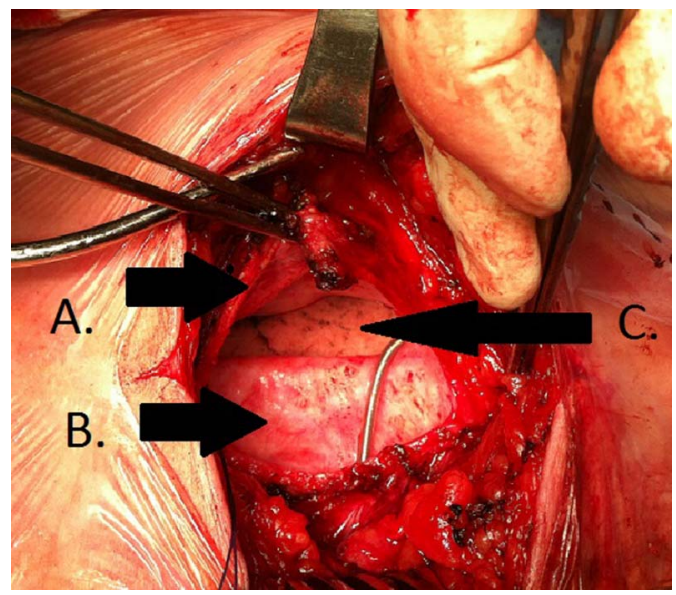

Figure 2 Intraoperative pictures: (A) hernia sac, (B) neck of defect and (C) left lung. warranted a thoracotomy to reduce the hernia electively.

At operation a large neck at the level of the previous thoracotomy was found (figure 2 ). The adhesions were taken down and the neck was released. The previous thoracotomy defect was closed with a figure of eight non-absorbable ethibond suture; the sac was closed simply with polydioxone. The patient's recovery postoperatively was uneventful.

\section{Learning points}

- Lung hernias are rare and may be congenital or acquired. Acquired hernias may be spontaneous or secondary to trauma or surgery such as video-assisted thoracotomy or open thoracotomy. Patients often present with a history of cough. ${ }^{1}$

- The development of enhanced operative techniques in cardiac and thoracic surgery allows a larger and more diverse cohort of patients undergoing procedures. It is likely, therefore, that the incidence of lung hernias will increase and it is therefore important for clinicians to be aware of its diagnosis and surgeons to be mindful of its prevention by careful closure of thoracotomy wounds. ${ }^{2}$

- Patients particularly at risk are those with raised intrathoracic pressures, chronic obstructive pulmonary disease, obesity, diabetes or malnourished patients. However it is not that that chest wall defects alone are sufficient to cause lung hernias. ${ }^{2}$
To cite: Bagenal JD, Capoun R, Casali G. BMJ Case Rep Published online: [please include Day Month Year] doi:10.1136/bcr-2013 009317
Competing interests None.

Patient consent Obtained.

Provenance and peer review Not commissioned; externally peer reviewed.

\section{REFERENCES}

1 Sonett J, O'Shea M, Caushaj P, et al. Hernia of the lung: case report and literature review. Ir J Med Sci 1994;163:410-12.

2 Temes RT, Talbot WA, Green DP, et al. Herniation of the lung after video-assisted thoracic surgery. Ann Thorac Surg 2001;72:606-7. 


\section{Images in...}

Copyright 2013 BMJ Publishing Group. All rights reserved. For permission to reuse any of this content visit http://group.bmj.com/group/rights-licensing/permissions.

BMJ Case Report Fellows may re-use this article for personal use and teaching without any further permission.

Become a Fellow of BMJ Case Reports today and you can:

- Submit as many cases as you like

- Enjoy fast sympathetic peer review and rapid publication of accepted articles

- Access all the published articles

- Re-use any of the published material for personal use and teaching without further permission

For information on Institutional Fellowships contact consortiasales@bmjgroup.com

Visit casereports.bmj.com for more articles like this and to become a Fellow 